\title{
Wanda Skoczylas*
}

\section{POMIAR DOKONAŃ W ZARZĄDZANIU POMYSŁAMI PRACOWNIKÓW PRZEDSIĘBIORSTW}

\section{WPROWADZENIE}

Podstawowym źródłem przewagi konkurencyjnej przedsiębiorstwa - bardziej niż poziom kosztów - jest innowacyjność i przedsiębiorczość. Obecnie innowacje uznaje się za lokomotywę rozwoju gospodarczego. Towarzyszą one ludziom, określając ich sposób życia i pracy. Znaczenie innowacji powoduje, że są one przedmiotem licznych badań, których wynikiem są nowe ich rozumienie i definiowanie. W analizach innowacyjności przywoływana jest definicją innowacji zaproponowana przez Organizację Współpracy Gospodarczej i Rozwoju w trzeciej edycji Podręcznika Oslo. Obecnie więc innowacja to wdrożenie w praktyce gospodarczej nowego lub znaczqco udoskonalonego produktu, usługi lub procesu, $w$ tym także wdrożenie nowej metody marketingowej lub organizacyjnej redefiniujacej sposób pracy lub relacje firmy $z$ otoczeniem ${ }^{1}$. Szersza analiza charakteru innowacji w krajach, w których konkurencyjność oparta jest na innowacjach pozwoliła zdefiniować nowe cechy tego zjawiska. Podkreśla się, że innowacja obecnie:

- powstaje przy udziale większej niż poprzednio liczby uczestników,

- powstaje dzięki krzyżowaniu się i fuzji większej niż dotychczas liczby obszarów wiedzy,

- jest tworzona w ramach bardziej niż dotąd zróżnicowanych mechanizmów (innowacje otwarte, popytowe, innowacje zamknięte, tworzone w ramach konsorcjów itd.),

${ }^{*}$ Dr hab. prof. US, Uniwersytet Szczeciński, Instytut Rachunkowości.

${ }^{1}$ M. B u kow s ki, A. S z po n ar, A. Ś ni e g o c ki, Potencjat i bariery polskiej innowacyjności, Instytut Badań Społecznych, Warszawa 2012, s. 3. Podobnie [w:] Podręcznik Oslo. Zasady gromadzenia $i$ interpretacji danych dotyczacych innowacji, wyd. 3, OECD/Eurostat, tłum. D. Przepiórowska, Warszawa 2008, s. 48. 
- przebiega w ramach coraz bardziej zróżnicowanego środowiska (konsorcja badawcze, ośrodki transferu technologii i platformy technologiczne, nowe firmy technologiczne, firmy kapitału ryzyka, wiedzochłonne usługi biznesowe KIBS - Knowledge Intensive Business Services, klastry, usługi non-profit a także, że:

- w działalności innowacyjnej kładzie się silniejszy niż dotąd nacisk na decentralizację zarządzania projektami, plastyczność organizacji, autonomie personelu, pobudzanie kreatywności, budzenie wzajemnego zaufania, komunikację i przywództwo ${ }^{2}$.

Zasadniczym źródłem innowacji w dalszym ciągu jest nauka, a więc laboratoria naukowo-badawcze funkcjonujące na styku czystej nauki (badań podstawowych) i przemysłu. Wśród działań wspierających rozwój społeczno-gospodarczy $\mathrm{m}$. in. Polski znajdują się więc inwestycje $\mathrm{w}$ sferę $\mathrm{B}+\mathrm{R}$, a w tym w kadrę i infrastrukturę, umożliwiające prowadzenie prac badawczych na najwyższym poziomie i uzyskanie wyników przydatnych gospodarczo ${ }^{3}$.

W nowej gospodarce wiedzy oprócz wymienionych tzw. twardych czynników generowania innowacji coraz większego znaczenia nabierają czynniki miękkie, a w tym zwłaszcza kapitał ludzki. Pracownicy obecnie są aktywnymi uczestnikami procesu wytwarzania. Liczy się ich wiedza, umiejętności i kompetencje zdobyte najczęściej poza miejscem pracy i przemieszczające się wraz z pracownikiem. Kluczowymi czynnikami sukcesu przedsiębiorstwa stają się więc idee, pomysły generowane przez wysoko wykwalifikowanych pracowników. Ich świadomość innowacyjna sprawia, że starają się oni podnosić swoje kwalifikacje oraz poszerzać posiadane zasoby wiedzy i umiejętności, są także otwarci na sygnały płynące $z$ otoczenia, dążą do ich zrozumienia i wykorzystania z korzyścią dla siebie, firmy, w której pracują, a także miejscowości i regionu w którym żyją. W tym nurcie mieszczą się nowe trendy społeczno-gospodarcze tj. crowdsourcing, czyli działania firm, które w poszukiwaniu nowych rozwiązań zwracają się m. in. do swoich pracowników. Poprawa pozycji konkurencyjnej przedsiębiorstwa realizowana może być bowiem przez odpowiednie motywowanie pracowników oraz tworzenie warunków do zgłaszania propozycji ulepszenia produktów, procesu lub serwisu ${ }^{4}$. Na uwagę zasługuje w szczególności, w sferze organizacji i zarządzania wdrożenie zarządzania pomysłami

${ }^{2}$ New forms of innovations: Challenges for policy-making, DSTI/STP/TIP(2009)6; 2009 Interim Report On The OECD Innovation Strategy SG/INNOV(2009)1/REV1, [za:] J. Ko złow -

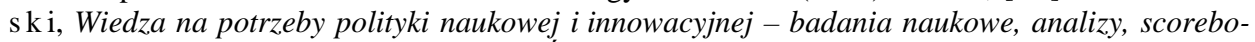
ardy, [w:] P. Zadu ra-Li ch ot a (red.), Świat innowacyjnego spoteczeństwa. Trendy na najblizsze lata, PARP, Warszawa 2013, s. 23.

${ }^{3}$ A. Giza-Poleszczuk, R. Włoch, Innowacje a spoteczeństwo, [w:] P. Zadura- Li chota (red.), Świat innowacyjnego społeczeństwa. Trendy na najbliższe lata, PARP, Warszawa 2013, s. 71-72.

${ }^{4} \mathrm{~S}$. Ło bejko, Mierzenie efektów polityki innowacyjnej. Wybrane rankingi i wskaźniki innowacyjności oraz trendy na przyszłość, [w:] P. Z a du r a - Li c ho t a (red.), Świat innowacyjnego społeczeństwa. Trendy na najbliższe lata, PARP, Warszawa 2013, s. 59 i nast. 
i zharmonizowanie go z zarządzaniem innowacjami. Skuteczność zarządzania pomysłami uzależniona jest $\mathrm{w}$ dużym stopniu od opracowania i wykorzystania do sterowania w tym obszarze odpowiednich rozwiązań w zakresie pomiaru.

Celem artykułu jest więc przedstawienie możliwych rozwiązań w zakresie pomiaru dokonań na potrzeby zarządzania pomysłami.

\section{ZARZĄDZANIE POMYSŁAMI A ZARZĄDZANIE INNOWACJAMI W STEROWANIU WYNIKAMI PRZEDSIĘBIORSTWA}

Nowe pojęcie innowacji eksponujące rolę pracowników może być podstawą połączenia $\mathrm{w}$ przedsiębiorstwie zarządzania innowacjami z zarządzaniem pomysłami, które obejmuje różne aktywności, służące osiagnnięciu korzyści z pomysłów, usprawnień formułowanych przez pracowników przedsiębiorstwa. Korzenie zarządzania pomysłami sięgają działalności racjonalizatorskiej. Racjonalizacja to w najbardziej ogólnym ujęciu działalność zmierzająca do osiagnięcia $w$ jakiejś dziedzinie zamierzonego celu w sposób doskonalszy od poprzednio stosowanego, usprawnienie a racjonalizator to autor pomystu racjonalizatorskiego; człowiek wprowadzajacy usprawnienie ${ }^{5}$. Zdefiniowaną $\mathrm{w}$ powyższy sposób racjonalizację zalicza się do sfery aktywności umysłowej człowieka, określanej mianem wynalazczości. Jest więc jak stwierdza A. Szewc formą twórczości intelektualnej człowieka, czyli działalnością zmierzającą do kreowania dzieł odznaczających się nowością światową (np. wynalazki), oryginalnością (utwory, artystyczne wykonania), pięknem (dzieła sztuki, wzory zdobnicze), prawdziwością lub trafnością sądów (dzieła naukowe), walorami użytkowymi (wzory użytkowe) itp. ${ }^{6}$ Racjonalizacja jest procesem naturalnym i pożądanym w każdej gospodarce.

Obecnie obowiązująca definicja projektu racjonalizatorskiego jest mało precyzyjna. Zgodnie $\mathrm{z}$ art. 23 Kodeksu cywilnego twórczość naukowa, artystyczna, wynalazcza i racjonalizatorska jest dobrem osobistym człowieka i pozostaje pod ochrona prawa cywilnego niezależnie od ochrony przewidzianej w innych przepisach ${ }^{7}$. Natomiast w prawie własności przemysłowej (PWP) zapisano, że o tym co jest projektem racjonalizatorskim decyduje przedsiębiorca. W rozumieniu ustawy, jest nim każde rozwiazanie nadajace się do wykorzystania, niebędace wynalazkiem podlegajacym opatentowaniu, wzorem użytkowym, wzorem przemystowym lub topografia uktadu scalonego ${ }^{8}$.

\footnotetext{
${ }^{5}$ Stownik Wyrazów Obcych PWN, Wydawnictwo Naukowe PWN, Warszawa, s. 620.

${ }^{6}$ A. S zew c, Racjonalizacja $w$ zaktadzie pracy. Poradnik dla racjonalizatorów i przedsiębiorców, Polska Agencja Rozwoju Przedsiębiorczości, Warszawa 2007, s. 18.

${ }^{7}$ Ustawa z dnia 23 kwietnia 1964 r. Kodeks cywilny, DzU 1964, nr 16, poz. 93, z późn. zm.

${ }^{8}$ Ustawa z dnia 23 stycznia 2004 r. o zmianie ustawy - Prawo wtasności przemystowej, DzU 2004, nr 33, poz. 286, w art. 7 ust. 2.
} 
Dążenie do osiągnięcia oczekiwanych wyników finansowych stymuluje od nieustannej inwencji we wszystkich obszarach działalności przedsiębiorstwa. W ostatnich latach zarządzanie pomysłami zajmuje się więc nie tylko zgłoszonymi pomysłami wnioskami racjonalizatorskimi i z nich wynikającymi korzyściami, ale staje się funkcją zarządzania ${ }^{9}$. W organizacji uczącej się zdolność do uczenia się osiąga się właśnie przez otwartość pracowników na nowe idee i trendy oraz stałe się ich doskonalenie. Zadaniem organizacji jest tym samym inicjowanie i wspieranie tych działań pracowniczych, które ostatecznie powodują jej ciagłą ewolucję ${ }^{10}$.

W organizacji uczącej się proces innowacyjny ma charakter kompleksowy i integruje zarówno zarządzanie pomysłami jak i innowacjami. Jeżeli przyjąć za podstawę definicję innowacji OECD to jak już wspomniano zarządzanie innowacjami obejmuje wdrożenie $\mathrm{w}$ praktyce gospodarczej nowego lub znacząco udoskonalonego produktu, usługi lub procesu, w tym także wdrożenie nowej metody marketingowej lub organizacyjnej redefiniującej sposób pracy lub relacje firmy z otoczeniem, a więc fazę realizacji. Wszystkie działania poprzedzające wdrożenie innowacji pozostają w sferze zarządzania pomysłami (rys. 1).

Jak wynika z rys. 1 wygenerowanie, pozyskanie, gromadzenie, ocena i selekcja pomysłów składają się na kolejne fazy zarządzania pomysłami. Proces ten w fazie oceny i selekcji projektów łączy się z procesem innowacyjnym, który obejmuje także realizację, a więc przekazanie do realizacji, realizację i wprowadzenie na rynek ${ }^{11}$.

${ }^{9}$ Zarządzanie pomysłami definiuje się jako systematyczne promowanie idei i inicjatyw pracowników lub nieformalnych grup pracowników z korzyścią dla przedsiębiorstwa i jego pracowników. Z definicji wynika, że zarządzanie pomysłami jest kompleksowym systemem, który charakteryzuje się systematycznością, a nie przypadkowością i jednorazowością, promocją, a więc aktywną rolą przedsiębiorstwa lub jego kierownictwa we wspieraniu pomysłów pojedynczych pracowników lub grup pracowników oraz osiaganymi ilościowymi i jakościowymi korzyściami przedsiębiorstwa i pracowników. Celem zarzadzania ideami jest poprawa jakości produktu i procesu, wzrost zadowolenia pracowników oraz tworzenie wartości przez szybką realizację pomysłów. W zarząazzaniu idami wyróżnić można dwa rodzaje celów, a więc cele jakościowe, tj. lepsza współpraca lub zadowolenie pracowników oraz ilościowe czyli oszczędności lub poprawa produktywności. Por. Erfolgsfaktor Ideenmanagement: Kreativität im Vorschlagswesen, Deutsches Institut für Betriebswirtschaft GmbH, Erich Schmidt Verlag, Berlin 2003, s. 22-23.

${ }^{10}$ P. M. S e n g e, Piata dyscyplina, Oficyna Ekonomiczna, Kraków 2003.

${ }^{11} \mathrm{~W}$ literaturze spotyka się szereg innych modeli zarządzania innowacjami. Na przykład w modelu siedmiokąta występuje siedem osi odpowiadających poszczególnym sferom zarządzania innowacjami, a mianowicie: zmianie strategii zarządzania, realizacji projektów badawczo-rozwojowych, kompetencji dla innowacji, poszukiwania okazji do innowacji, bezpieczeństwa innowacyjnej własności intelektualnej, finansowania działalności innowacyjnej oraz wspierania postaw innowacyjnych. Por. M. K a rli k, Zarzqdzanie innowacjami w przedsiębiorstwie, Wydawnictwo Poltext, Warszawa 2012, s. 136-151. 


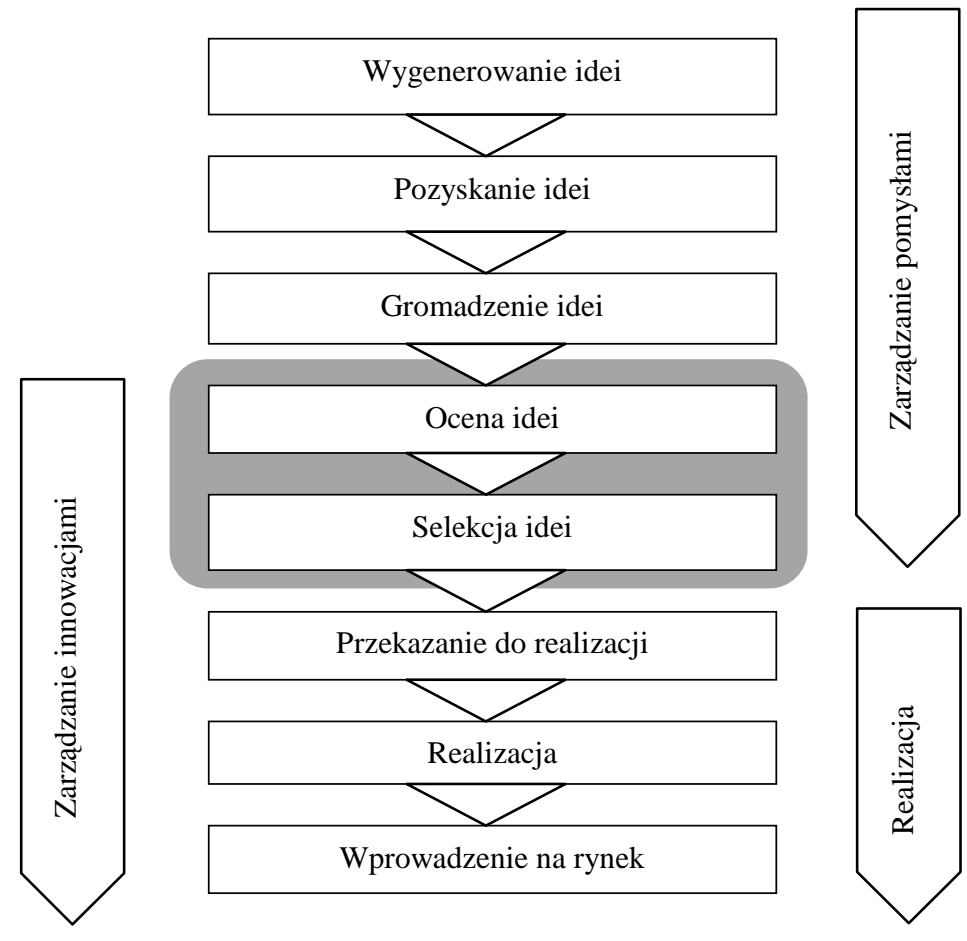

Rys. 1. Proces innowacyjny

Źródło: D. V ah s, R. B u r me i s ter, Innovationsmanagement: Von Produktidee zu erfolgreichen Vermarktung, Stuttgart 2005, wyd. 3, s. 135, [za:] M. Haupenthal, B. Pede11, P. Rötze l, Verknüpfung von Ideen- und Innovationsmanagement. Empirische Untersuchung der Performance-Wirkungen und Ableitung von Gestaltungsansätzen, „Controlling” 2013, nr 3.

Połączenie zarządzania innowacjami i zarządzania pomysłami ma szereg walorów, do których zaliczyć można:

- wygenerowanie nowych innowacji przez wykorzystanie pomysłów pracowników;

- wytworzenie dodatkowych efektów z połączenia dotychczas oddzielnie realizowanego zarządzania i pomysłami i innowacjami i ich organizacyjnego podziału. Wiedza i doświadczenie pochodzące ze współpracy obu obszarów przyczyniają się do stworzenia wspólnej bazy wiedzy;

- efekt skali wynikający z obniżki kosztów opracowania jednego pomysłu. Efekt skali osiagga się w fazie selekcji i oceny projektów. Wspólne opracowywanie pomysłów i projektów innowacyjnych powoduje, co prawda wzrost liczby zatrudnionych pracowników, ale jest on mniejszy, niż liczba opracowywanych pomysłów. W rezultacie maleją koszty jednostkowe opracowania pomysłu; 
- oszczędność kosztów przez optymalizację procesu badawczo-rozwojowego. Około 70\% kosztów produktu gotowego zostaje określone w fazie badawczo-rozwojowej. Zasadne jest więc wykorzystanie w tym momencie także zarządzania pomysłami, jako instrumentu doskonalenia procesu;

- większą skuteczność wdrażania pomysłów pracowniczych, stanowiących element przewagi konkurencyjnej;

- większą motywację i partycypację pracowników w rozwoju przedsiębiorstwa;

- oszczędność czasu wdrożenia pomysłów. Integracja procesu decyzyjnego pozwala wcześniej wyodrębnić pomysły spełniające wymagania innowacji i te które tych wymagań nie spełniają i będą przedmiotem dalszego zarządzania pomysłami;

- większy odsetek wdrożeń pochodzących zarówno z pomysłów jak i działalności badawczo-rozwojowej ${ }^{12}$.

Mankamentami są natomiast:

- duża liczba zgłaszanych pomysłów, które nie nadają się do realizacji jako projekty badawczo-rozwojowe, skutkująca wzrostem zapotrzebowania na dodatkowe środki i pracowników, których zadaniem jest ich selekcja;

- powstające konflikty, których źródłem są zróżnicowane cele obu obszarów zarządzania. Celem zarządzania pomysłami jest duża liczba drobnych ulepszeń obecnych produktów. Natomiast działalność innowacyjna koncentruje się na nielicznych ale znaczących i korzystnych innowacjach. Ta rozbieżność celów obu obszarów skutkuje różnorodnym postrzeganiem korzyści z pomysłów, i w konsekwencji determinuje zróżnicowane zachowania. Zarządzający pomysłami mogą uznać, że ich rozwiązanie zostało zbyt wcześnie odrzucone przez zarządzających innowacjami, jako posiadające zbyt mały potencjał innowacyjny;

- w przypadku połączenia tylko zadań obu obszarów, bez ich scalenia organizacyjnego może wystąpić powielenie odpowiedzialności i kompetencji. W rezultacie czego decyzje nie są podejmowane lub też powielane, a cały proces innowacyjny zostaje spowolniony ${ }^{13}$.

Korzyści wynikające z połączenia obu obszarów są niewątpliwie na tyle znaczące, a mankamenty możliwe do eliminacji, że tendencja łącznego ich rozpatrywania zwłaszcza obecnie znajduje coraz szerszą akceptację. Wśród działań wymagających rozwiązania występuje też problem pomiaru dokonań.

${ }^{12}$ M. H a u p e n th a l, B. P e d e 11, P. Röt z e 1, Verknüpfung von Ideen- und Innovationsmanagement. Empirische Untersuchung der Performance-Wirkungen und Ableitung von Gestaltungsansätzen, „Controlling” 2013, nr 3.

${ }^{13}$ Ibidem. 


\section{PODMIOTOWE PODEJŚCIE DO POMIARU DOKONAŃ AKTYWNOŚCI PRACOWNICZEJ}

Z literatury i praktyki gospodarczej znane jest słynne powiedzenie Petera Druckera: Jeśli nie można czegoś zmierzyć, nie da się tym zarzadzać. Zostało ono później zmodyfikowane przez Billa Hawletta i obecnie mówi się, że: Nie można zarzqdzać tym, co nie jest mierzalne, co jest mierzalne, może być zrobio$n e$. Wynika $\mathrm{z}$ tego, że pomiar osiągniętych $\mathrm{w}$ przeszłości wyników, a przede wszystkim generatorów tych wyników czyli dokonań i ich ocena, jest koniecznym elementem budowy organizacji uczącej się i osiaggania przewagi konkurencyjnej w długim okresie. Pomiar i ocena funkcjonowania organizacji umożliwiają podejmowanie efektywniejszych i skuteczniejszych decyzji oraz lepszą alokację zasobów. Przyczyniają się do ograniczenia ryzyka. Ułatwiają komunikację między członkami organizacji i pozostałymi interesariuszami oraz kształtowanie się nowej kultury organizacyjnej i budowanie organizacji cieszącej się publicznym zaufaniem ${ }^{14}$.

Pomiar osiagniętych dokonań w sferze szeroko rozumianych innowacji nieustannie ewoluuje. W statystyce dyskutuje się i wprowadza nowe, emergentne wskaźniki ${ }^{15}$. Również w przedsiębiorstwach wdrażane są rozwiązania dostosowane do potrzeb decydentów.

W zarządzaniu pomysłami wykorzystać można dwa podejścia do pomiaru dokonań w zakresie aktywności pracowników, a mianowicie:

- pojedyncze, klasyczne wskaźniki,

- systemy wskaźników.

Najczęściej stosowanymi klasycznymi wskaźnikami są:

- liczba zgłoszonych pomysłów przypadająca na jednego pracownika,

- liczba zrealizowanych pomysłów w stosunku do liczby zgłoszonych pomysłów,

- liczba pracowników zgłaszających pomysły w stosunku do łącznej liczby pracowników, osiągnięte korzyści w danym okresie przypadające na jeden wdrożony pomysł w tym okresie,

- osiagnięte korzyści w stosunku do czasu opracowania pomysłu.

Przedstawione wskaźniki odzwierciedlają aktywność pracowników oraz jej efektywność. Mogą być też przedmiotem badań statystycznych. Przedsiębiorstwo jest jednak zainteresowane wskaźnikami, które bezpośrednio pokazują wpływ aktywności pracowników na wynik przedsiębiorstwa. $\mathrm{Z}$ tego więc powodu większe jest zainteresowanie systemami wskaźników tak w zarządzaniu całym przedsiębiorstwem jak i wyodrębnionymi obszarami jego działalności.

${ }^{14}$ W. S k o c zylas, Wskaźniki i systemy wskaźników w pomiarze dokonań przedsiębiorstw, Uniwersytet Szczeciński, Rozprawy i Studia T.CMXXXIX (865), Wydawnictwo Naukowe Uniwersytetu Szczecińskiego, Szczecin 2013, s. 9.

${ }^{15}$ S. Łobej k o, op. cit., s. 41-64. 
Systemem wskaźników antycypującym przyszły rozwój przedsiębiorstwa jest zyskująca coraz większą popularność strategiczna karta wyników. Umożliwia ona przełożenie wizji, misji i strategii na cele i wskaźniki w czterech wzajemnie ze sobą powiązanych płaszczyznach, a mianowicie: finansowej, klientów, procesów wewnętrznych oraz wiedzy i rozwoju. Obecnie strategiczna karta wyników przez zintegrowanie aktywów niematerialnych przedsiębiorstwa ze strategią staje się podstawą do uzyskania synergii organizacyjnej. Osiaggnięciu znaczących rezultatów w zakresie strategicznych działań przedsiębiorstwa uzależnione jest od przestrzegania pięciu zasad, takich jak:

- mobilizacja do zmian,

- przetłumaczenie strategii na działania operacyjne, co wymaga zidentyfikowania kluczowych czynników sukcesu, a następnie dopiero ich pomiaru,

- dopasowanie organizacji do strategii, co wymaga wypracowania konsensusu pomiędzy komórkami w przedsiębiorstwie, ale też pomiędzy partnerami zewnętrznymi,

- uczynienie strategii codziennym zadaniem pracowników, skutkujące zaangażowaniem wszystkich pracowników w poszukiwanie przewagi konkurencyjnej przedsiębiorstwa,

- rozumienie strategii jako procesu ciagłego ${ }^{16}$.

Odpowiednio zmierzona aktywność, zaangażowanych $\mathrm{w}$ poszukiwanie przewagi konkurencyjnej przedsiębiorstwa, pracowników powinna więc znaleźć swoje odzwierciedlenie w płaszczyźnie wiedzy i rozwoju. Jej efekty, przez zależności przyczynowo skutkowe, właściwe temu sposobowi pomiaru dokonań przenoszone są na płaszczyznę procesów wewnętrznych. Można więc przedstawić i określić na mapie strategii ich wpływ na: poprawę innowacyjności i jakości produktów i procesów, skrócenie czasu procesu czy też obniżkę kosztów. Produkt będący rezultatem tych działań lepiej spełnia oczekiwania ważnych klientów ze zdefiniowanych segmentów rynku i tym samym w wymierny sposób zwiększa korzyści właścicieli.

\section{WYKORZYSTANIE ZAŁOŻEŃ STRATEGICZNEJ KARTY WYNIKÓW NA POTRZEBY WYODRĘBNIONEGO PRZEDMIOTOWO I ORGANIZACYJNIE ZARZĄDZANIA POMYSLAMI}

Wprowadzenie zarządzania pomysłami skutkuje również podejmowaniem prób konstruowania strategicznych kart wyników, w zarządzaniu tym właśnie obszarem. Zgodnie z ideą tego systemu pomiaru dokonań wyodrębnia się więc płaszczyzny, cele i wskaźniki ich przykładową strukturę zawiera tab. 1.

${ }^{16}$ J. Ś w i e rk, Mapa strategii i strategiczna karta wyników w planowaniu działań przedsiębiorstwa. Studium teoretyczno-empiryczne, Wydawnictwo Uniwersytetu Marii Curie-Skłodowskiej, Lublin 2009, s. 56-57. 
Tabela 1

Płaszczyzny, cele i wskaźniki strategicznej karty wyników w zarządzaniu pomysłami

\begin{tabular}{|c|c|c|}
\hline Płaszczyzna & Cel & Wskaźnik \\
\hline \multirow[t]{2}{*}{$\begin{array}{l}\text { Wyników, } \\
\text { korzyści }\end{array}$} & $\begin{array}{l}\text { 1. Budowa konkurencyjnego } \\
\text { systemu zarządzania pomysłami }\end{array}$ & $\begin{array}{l}\text { 1.1. Formuła Deutsches Institut für Be- } \\
\text { triebswirtschaft }\end{array}$ \\
\hline & 2. Osiągnięte efekty & $\begin{array}{l}\text { 2.1. Korzyści przypadające na jednego } \\
\text { pracownika }\end{array}$ \\
\hline \multirow[t]{5}{*}{ Pracowników IM } & $\begin{array}{l}\text { 1. Wzrost ilości propozycji } \\
\text { usprawnień }\end{array}$ & $\begin{array}{l}\text { 1.1. Liczba zgłaszających pomysły } \\
\text { w stosunku do liczby uprawnionych do } \\
\text { składania propozycji }\end{array}$ \\
\hline & $\begin{array}{l}\text { 2. Poprawa jakość propozycji } \\
\text { usprawnień }\end{array}$ & $\begin{array}{l}\text { 2.1. Premia przypadająca na jeden pozy- } \\
\text { tywnie oceniony projekt }\end{array}$ \\
\hline & $\begin{array}{l}\text { 3. Zapewnienie ilości propozycji } \\
\text { usprawnień }\end{array}$ & 3.1. Współczynnik Giniego \\
\hline & $\begin{array}{l}\text { 4. Wzrost jakości wnioskodaw- } \\
\text { ców }\end{array}$ & $\begin{array}{l}\text { 4.1. Przyrost liczby pracowników zgła- } \\
\text { szających pomysły do ilości pracowni- } \\
\text { ków uprawnionych do składania pomy- } \\
\text { słów }\end{array}$ \\
\hline & $\begin{array}{l}\text { 5. Uaktywnianie wnioskodaw- } \\
\text { ców dotychczas niezaangażowa- } \\
\text { nych }\end{array}$ & $\begin{array}{l}\text { 5.1. Liczba nowych wnioskodawców } \\
\text { do łącznej liczby zgłaszających pomysły }\end{array}$ \\
\hline \multirow[t]{2}{*}{$\begin{array}{l}\text { Procesów } \\
\text { wewnętrznych }\end{array}$} & $\begin{array}{l}\text { 1. Poprawa szybkości opracowa- } \\
\text { nia pomysłów }\end{array}$ & $\begin{array}{l}\text { 1.1. Skrócenie czasu opracowania pomy- } \\
\text { słu od momentu sformułowania do oceny } \\
\text { pomysłu } \\
\text { 1.2. Skrócenie czasu pomiędzy pozytyw- } \\
\text { ną oceną projektu a jego realizacją }\end{array}$ \\
\hline & $\begin{array}{l}\text { 2. Poprawa efektywności opra- } \\
\text { cowania }\end{array}$ & $\begin{array}{l}\text { 2.1. Wzrost liczby pozytywnie ocenio- } \\
\text { nych projektów } \\
\text { 2.2. Wzrost liczby zrealizowanych pro- } \\
\text { jektów pozytywnie ocenionych }\end{array}$ \\
\hline \multirow[t]{4}{*}{ Wiedzy i rozwoju } & $\begin{array}{l}\text { 1. Wzrost motywacji pracowni- } \\
\text { ków IM w składaniu pomysłów }\end{array}$ & $\begin{array}{l}\text { 1.1. Wskaźnik zadowolenia (średnia ocen } \\
\text { punktów ankiety) }\end{array}$ \\
\hline & $\begin{array}{l}\text { 2. Wzrost motywacji inspekto- } \\
\text { rów, rzeczoznawców, przedsta- } \\
\text { wicieli racjonalizatorów w gene- } \\
\text { rowaniu pomysłów }\end{array}$ & $\begin{array}{l}\text { 2.1. Wskaźnik zadowolenia (średnia ocen } \\
\text { punktów ankiety) }\end{array}$ \\
\hline & $\begin{array}{l}\text { 3. Wzrost wykształcenia pra- } \\
\text { cowników IM }\end{array}$ & $\begin{array}{l}\text { 3.1. Liczba uczestników kreatywnych } \\
\text { szkoleń do liczby uprawnionych do skła- } \\
\text { dania pomysłów }\end{array}$ \\
\hline & $\begin{array}{l}\text { 4. Poprawa zadowolenie pra- } \\
\text { cowników IM z opracowania } \\
\text { pomysłów }\end{array}$ & $\begin{array}{l}\text { 4. 1. Liczba odwołań do liczby ocenia- } \\
\text { nych usprawnień }\end{array}$ \\
\hline
\end{tabular}

Źródło: opracowanie własne na podstawie: M. Ja n kow s ki, Das integrierte Ideenmanagement in der Balanced Scorecard: Ein praxisrelevantes Konzept am Beispiel eines metallveraibantenden Mittelständlers, GRIN Verlag, München 2009, s. 88-104. 
Na uwagę w przedstawionym zestawie wskaźników zasługuje formuła Deutsches Institut für Betriebswirtschaft wykorzystywana do oceny jakości systemu zarządzania ideami. Formuła ta ma następującą postać:

(1000 x liczba zrealizowanych pomysłów racjonalizatorskich przez jednego zatrudnionego +3 x przewidywane korzyści względnie oszczędności na jednego zatrudnionego) x udziat pomysłodawców w ogólnej liczbie zatrudnionych ${ }^{17}$.

Jej zastosowanie umożliwia $\mathrm{w}$ dalszym ciągu pozycjonowanie przedsiębiorstwa wśród najlepszych lub też w danej branży.

Współczynnik Giniego, jako miara ryzyka, wykorzystywany jest w ocenie niebezpieczeństwo spadku liczby składanych wniosków.

\section{ZAKOŃCZENIE}

Jak wynika $\mathrm{z}$ przedstawionych rozważań obecnie wypracowane zostały mniej lub bardziej złożone podejścia do pomiaru dokonań właściwe w zarządzaniu pomysłami. $Z$ wymienionych większą wartość poznawczą i przydatność praktyczną ma włączenie pomiaru aktywności pracowniczej w strukturę strategicznej karty wyników, a w tym w płaszczyznę wiedzy i rozwoju. Eksponowane w niej zależności przyczynowo-skutkowe, pozwalają nie tylko ocenić występujący potencjał i jego wykorzystanie, ale też pokazują w poszczególnych obszarach efekty niefinansowe, ale też i finansowe, i umożliwiają sterowanie nimi. Podejście to odpowiada podejściu podmiotowemu stosowanemu w innowacjach. Taki sposób pomiaru dokonań umożliwia aktywne zarządzanie pomysłami ze wszystkim pozytywnymi skutkami. W przypadku wyodrębnienia przedmiotowego i organizacyjnego implementacja strategicznej karty wyników na potrzeby realizacji zarządzania pomysłami umożliwia lepsze funkcjonowanie całego systemu. Pomiar dokonań w tym wypadku jest aktywnym instrumentem bieżącego zarządzania i pozwala eliminować występujące często mankamenty zarządzania pomysłami, jak:

- brak zainteresowania oceniających projekty ich wdrożeniem,

- rozliczanie z ilości zgłoszonych projektów, a nie możliwych efektów,

- koncentracja na bieżących wynikach i unikanie dodatkowego obciążenia z tytułu nowych projektów, skutkująca brakiem ich wdrożenia,

- brak wiedzy i fachowości osób przeprowadzających konkursy,

${ }^{17}$ dib-Report 2008 Ideenmanagement in Deutschland. Jahresbericht 2008 des Deutschen Instituts für Betriebswirtschaft (dib) Frankfurt am Main, http://www.dib.de/fileadmin/Dateien/ Downloads/Dokumente/dib-Report_2008.pdf. 
- tworzenie sztucznych systemów motywacyjnych, będących powodem sztucznej konkurencji i braku zainteresowania ze strony specjalistów zaangażowanych w dopracowanie pomysłów ${ }^{18}$.

\section{BIBLIOGRAFIA}

Bukowski M., Szponar A., Śniegocki A., Potencjat i bariery polskiej innowacyjności, Instytut Badań Społecznych, Warszawa 2012.

dib-Report 2008 Ideenmanagement in Deutschland Jahresbericht 2008 des Deutschen Instituts für Betriebswirtschaft (dib) Frankfurt am Mai., http://www.dib.de/fileadmin/Dateien/Downloads/Dokumente/dib-Report_2008.pdf.

Erfolgsfaktor Ideenmanagement: Kreativität im Vorschlagswesen, Deutsches Institut für Betriebswirtschaft GmbH, Erich Schmidt Verlag, Berlin 2003.

Giza-Poles zczuk A., Włoch R., Innowacje a społeczeństwo, [w:] P. Zadura-Lichota (red.), Świat innowacyjnego społeczeństwa. Trendy na najbliższe lata, PARP, Warszawa 2013.

Haupenthal M., Pedell B., Rötzel P., Verknüpfung von Ideen- und Innovationsmanagement. Empirische Untersuchung der Performance-Wirkungen und Ableitung von Gestaltungsansätzen, „Controlling” 2013, nr 3.

J an kow ski M., Das integrierte Ideenmanagement in der Balanced Scorecard: Ein praxisrelevantes Konzept am Beispiel eines metallveraibantenden Mittelständlers, GRIN Verlag, München 2009.

Karlik M., Zarzqdzanie innowacjami w przedsiębiorstwie, Wydawnictwo Poltext, Warszawa 2012.

Ło bejko S., Mierzenie efektów polityki innowacyjnej. Wybrane rankingi i wskaźniki innowacyjności oraz trendy na przyszłość, [w:] P. Z a du ra-Li chota (red.), Świat innowacyjnego spoteczeństwa. Trendy na najbliższe lata, PARP, Warszawa 2013.

New forms of innovations: Challenges for policy-making, DSTI/STP/TIP(2009)6; 2009 Interim Report On The OECD Innovation Strategy SG/INNOV(2009)1/REV1, [za:] J. Kozłow -

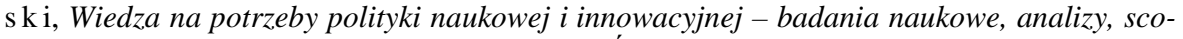
reboardy, [w:] P. Zadu ra-Lichota (red.), Świat innowacyjnego społeczeństwa. Trendy na najbliższe lata, PARP, Warszawa 2013.

Podręcznik Oslo. Zasady gromadzenia $i$ interpretacji danych dotyczqcych innowacji, wyd. 3, OECD/Eurostat, tłum. D. Przepiórowska, Warszawa 2008.

R u d olf T., Zarzadzanie pomystami, cz. I, http://manager.nf.pl/zarzadzanie-pomyslami-czesc-i,, 10250,18

S e n g e P. M., Piqta dyscyplina, Oficyna Ekonomiczna, Kraków 2003.

$\mathrm{S}$ k o c z y l a s W., Wskaźniki i systemy wskaźników w pomiarze dokonań przedsiębiorstw, Uniwersytet Szczeciński, Rozprawy i Studia T.CMXXXIX (865), Wydawnictwo Naukowe Uniwersytetu Szczecińskiego, Szczecin 2013.

Stownik Wyrazów Obcych PWN, Wydawnictwo Naukowe PWN, Warszawa.

S ze w c A., Racjonalizacja w zaktadzie pracy. Poradnik dla racjonalizatorów i przedsiębiorców, Polska Agencja Rozwoju Przedsiębiorczości, Warszawa 2007.

${ }^{18}$ T. Rud olf, Zarzadzanie pomystami, cz. I, http://manager.nf.pl/zarzadzanie-pomyslamiczesc-i,,10250,18. 
Ś w i erk J., Mapa strategii i strategiczna karta wyników w planowaniu działań przedsiębiorstwa. Studium teoretyczno-empiryczne, Wydawnictwo Uniwersytetu Marii Curie-Skłodowskiej, Lublin 2009.

Ustawa z dnia 23 kwietnia 1964 r. Kodeks cywilny, DzU 1964, nr 16, poz. 93, z późn. zm.

Ustawa z dnia 23 stycznia 2004 r. o zmianie ustawy - Prawo wtasności przemystowej, DzU 2004, nr 33, poz. 286 , w art. 7 ust. 2.

Vahs D., Burme ister R., Innovationsmanagement: Von Produktidee zu erfolgreichen Vermarktung, wyd. 3, Stuttgart 2005, s. 135, [za:] M. H a u p e n th a 1, B. Pe de11, P. Röt ze 1, Verknüpfung von Ideen- und Innovationsmanagement. Empirische Untersuchung der Performance-Wirkungen und Ableitung von Gestaltungsansätzen, „Controlling” 2013, nr 3.

\section{Wanda Skoczylas}

\section{MEASUREMENT OF ACHIEVEMENTS IN MANAGEMENT IDEAS ENTERPRISE STAFF}

The purpose of this article is to present proposals for the purpose of measuring the achievements of management ideas. Been proposed two variants of measure. At first, according to the assumptions of the personal approach were presented indicators of activity of employees in the structure of the Balanced Scorecard. In the second variant, concerning the functioning of management ideas, extracted from the point of view of content and organization, was proposed use of a customized concept of the Balanced Scorecard.

Key words: knowledge management, idea management, performance measurement.

Tłum. Mgr Beata Gostomczyk 